\title{
Original Research \\ Applicability of water from the Bay of Gdańsk as a growth medium for mixotrophic culture of Platymonas subcordiformis
}

\author{
Magda Dudek ${ }^{1}$, Marcin Dębowski ${ }^{1, *}$, Anna Nowicka ${ }^{1}$, Joanna Kazimierowicz ${ }^{2}$, \\ Marcin Zieliński ${ }^{1}$ \\ ${ }^{1}$ Department of Environment Engineering, Faculty of Geoengineering, University of Warmia and Mazury in Olsztyn, 10-720 Olsztyn, Poland \\ ${ }^{2}$ Department of Water Supply and Sewage Systems, Faculty of Civil Engineering and Environmental Sciences, Bialystok University of Technology, \\ 15-351 Bialystok, Poland \\ *Correspondence: marcin.debowski@uwm.edu.pl (Marcin Dębowski) \\ Academic Editor: Ganesh D. Saratale \\ Submitted: 22 December 2021 Revised: 7 January 2022 Accepted: 8 January 2022 Published: 14 February 2022
}

\begin{abstract}
P. subcordiformis is a potentially promising species with commercial, environmental and technological viability for industrial applications. The great potential of these microalgae lies in their fast biomass growth, pollution resistance, and compatibility with different culture media. This study aimed to determine the efficiency of $P$. subcordiformis biomass production in a medium prepared with water from the Bay of Gdańsk. The tested medium supported high biomass growth rates which reached $317.58 \pm 42.31 \mathrm{mg}_{V S} / \mathrm{dm}^{3} \cdot \mathrm{d}$ in the best-performing variant, with a final concentration of $3493.3 \pm 465.4 \mathrm{mg}_{V S} / \mathrm{dm}^{3} \cdot \mathrm{d}$. In the autotrophic culture, nitrogen and phosphorus removal exceeded $98 \%$. Amending the mixotrophic culture with glucose did not affect $P$. subcordiformis concentrations. However, it did significantly limit the demand for nutrients in the biomass and reduced chlorophyll a production in the cells.
\end{abstract}

Keywords: Microalgae; Platymonas subcordiformis; Mixotrophic culture; Natural water; Growth medium

\section{Introduction}

Pushing forward the development and widespread take-up of environmentally-friendly, efficient and costeffective biomass production technologies represents an ongoing challenge to scientists, as well as a priority issue for operators of energy systems [1]. There have been numerous attempts to demonstrate that typical land energy crops can be used for this purpose [2,3]. However, the use of such plants requires appropriate agrotechnical procedures, marginal/degraded soils, natural fertilizers, as well as species of energy crops that must be carefully selected, fast-growing and resistant to environmental conditions [4].

However, this prevailing view has been contested by some opinions and publications. Life cycle analyses (LCA) have shown that mismanagement of traditional energy crop reserves may actually exacerbate greenhouse gas emissions [5]. There is an increasingly common view that intensive use of farmland for growing biofuel crops may lead to decreased global food supply and a significant positive pressure on food prices [6]. Such risks and limitations have also been acknowledged by European Union (EU) legislators. Reports on ILUC (Indirect Land Use Change Impacts), commissioned by the European Commission, call into question the environmental viability of biofuels produced from grain, root/tuber crops or oil crops [7]. As such, the feasibility of using food sources for biofuel production is an increasingly common thread in discussions at the EU level. It is generally assumed that these goals are to be achieved, e.g., by harnessing advanced biofuels made from alternative feedstocks [8].

Therefore, there is a real need to seek alternative sources of biomass, ones which would be both commercially and environmentally viable as a source of energy. Algae possess very high photosynthetic efficiency, can rapidly build biomass, are resistant to various contaminants and can be sited on land that is unsuitable for other purposes. Given these considerations, algae may represent a viable substitute for traditional energy cops. Algae also appear on the European list of feedstocks which, when used for biofuel production, can be double-counted for the purposes of determining biofuel energy content $[9,10]$. Microalgae biomass is also a rich source of carbohydrates, proteins, fatty acids, enzymes and fibers. In addition, algae are rich in vitamins and minerals, including vitamins $\mathrm{A}, \mathrm{C}, \mathrm{B}_{1}, \mathrm{~B}_{2}, \mathrm{~B}_{6}$, as well as niacin, iodine, potassium, iron, magnesium and calcium. Cyanobacteria and green algae are an excellent source of protein and saturated fatty acids, phycocyanin and betacarotene [11]. A dynamically developing direction is the production of astaxanthin, which is one of the main xanthophyll dyes [12]. Among the microalgae capable of producing astaxanthin is Haematococcus pluvialis [13]. Microalgae also have the ability to synthesize such fatty acids like, eicosapentaenoic acid (EPA 20: 5 w3) [14] and docosahexaenoic acid (DHA 22: $6 \omega 3$ ) $[15,16]$. The positive effect of DHA and other Omega-3 fatty acids on the cardiovascular system has been proven in many in vivo and in vitro experiments and clinical trials [17]. 
A key factor, which in many cases determines the costeffectiveness of energy production from algal biomass, is the choice of technology used to grow and separate the organisms [18]. Algae can be cultivated using various methods, beginning from strictly monitored methods in technologically advanced designs, to less predictable methods based on open systems [19]. Apart from the technology used to produce the biomass, the type and, most importantly - cost of the growth medium used also play a huge role [20]. Therefore, there have been attempts to identify relatively cheap methods which would harness various types of sewage, leachate, industrial effluent or waste water [21]. Use of natural water as growth medium is a novel area of research that very few papers have dealt with so far [22]. The vast majority of the data available pertain to producing microalgal biomass on media prepared from distilled water and chemical reagents that provide optimal conditions for microalgal growth $[23,24]$.

One promising species, which may be commercially, environmentally and technologically viable, is $P$. subcordiformis. Some literature reports show that these microorganisms can be a source of value-added substances such as sugars, proteins or fats, given optimal culture conditions [25]. The great potential of $P$. subcordiformis algae lies in their fast biomass growth, resistance to various types of pollution, high adaptability, and compatibility with different culture media of various physico-chemical parameters [26]. There is also a fast-expanding body of research on using $P$. subcordiformis planctonic algae by switching their metabolism towards hydrogen production [27,28].

This study aimed to determine the efficiency of biomass production on a mixotrophic $P$. subcordiformis culture. The medium was prepared with Bay of Gdańsk water as the base.

\section{Materials and methods}

\subsection{Experimental design}

The study was separated into two series with the growth medium as the differentiating factor. Series 1 (S1) utilized deionized water, whereas series 2 (S2) used water sourced from the Bay of Gdańsk. Each of the series was divided into two variants. In variant 1 (V1), the medium was supplemented exclusively with microelements required for optimal growth of $P$. subcordiformis. In the second variant (V2), the medium was amended with glucose as an external carbon source to expedite the growth of the microalgal population.

\subsection{Microalgal biomass}

The study used halophilous microalgae of the species P. subcordiformis, sourced from the UTEX collection (The University of Texas at Austin). The P. subcordiformis inoculum was transferred to the agar medium in a $20 \mathrm{~cm}^{3}$ tube. In the first phase, the microalgae were grown in sterilized Falcon tubes with an active volume of $50 \mathrm{~cm}^{3}$. After 11 days of culture, the biological specimens were transferred to DURAN bioreactors with a capacity of $1.0 \mathrm{dm}^{3}$ to initiate the second phase of growth. Air was supplied into the reactor via Mistral 200 peristaltic pumps with a flow rate of $200 \mathrm{dm}^{3} / \mathrm{h}$. The PBR was incubated in a Binder MB1 chamber (with a programmable controller) at $25 \pm 1.0^{\circ} \mathrm{C}$ and intermittently exposed to 5 klux white light. The experiment followed a $14 \mathrm{~h}$ light/10 h dark regime, in accordance with literature indications [29]. The bioreactors were pasteurized using a Tuttnauer 2840 EL-D autoclave at 121 ${ }^{\circ} \mathrm{C}$ for 15 minutes. In the first phase, the microalgae were grown in a medium prepared according to literature [29,30] (Table 1). The resultant biomass was used in the exact experiment.

Table 1. Composition of the synthetic medium used to grow

\begin{tabular}{lcc}
\multicolumn{3}{c}{ P. subcordiformis. } \\
\hline Constituent & Value & Unit \\
\hline $\mathrm{FeCl}_{3}$ & 1.30 & $\mathrm{mg} / \mathrm{dm}^{3}$ \\
$\mathrm{MnCl}_{2}$ & 0.36 & $\mathrm{mg} / \mathrm{dm}^{3}$ \\
$\mathrm{H}_{3} \mathrm{BO}_{3}$ & 33.60 & $\mathrm{mg} / \mathrm{dm}^{3}$ \\
$\mathrm{EDTA}$ & 45.00 & $\mathrm{mg} / \mathrm{dm}^{3}$ \\
$\mathrm{NaH}_{2} \mathrm{PO}_{4}$ & 20.00 & $\mathrm{mg} / \mathrm{dm}^{3}$ \\
$\mathrm{NaNO}_{3}$ & 100.00 & $\mathrm{mg} / \mathrm{dm}^{3}$ \\
$\mathrm{ZnCl}_{2}$ & 0.21 & $\mathrm{mg} / \mathrm{dm}^{3}$ \\
$\mathrm{CoCl}_{2}$ & 0.20 & $\mathrm{mg} / \mathrm{dm}^{3}$ \\
$\left(\mathrm{NH}_{4}\right)_{4} \mathrm{Mo}_{7} \mathrm{O}_{24}$ & 0.09 & $\mathrm{mg} / \mathrm{dm}^{3}$ \\
$\mathrm{CuSO}_{4}$ & 0.20 & $\mathrm{mg} / \mathrm{dm}^{3}$ \\
$\mathrm{VB}_{2}$ & 0.10 & $\mu \mathrm{g} / \mathrm{dm}^{3}$ \\
$\mathrm{VB} 1$ & 1.00 & $\mu \mathrm{g} / \mathrm{dm}^{3}$ \\
Parameter & Value & $\mathrm{Unit}$ \\
Salinity & $30-33$ & $\mathrm{ppt}$ \\
pH & $8.00-8.20$ & - \\
\hline
\end{tabular}

The profile of the microalgal biomass is presented in Table 2. Initial microalgal biomass with dry organic matter levels (VS) and chlorophyll levels during the exact experiment were kept at $200 \mathrm{mg}_{V S} / \mathrm{dm}^{3}$ and $0.1 \mu \mathrm{g} / \mathrm{dm}^{3}$. In all of the variants, $P$. subcordiformis was cultured over a period of 11 days. Samples for analysis were taken every $48 \mathrm{~h}$.

\subsection{Growth media}

The study used growth media with different profiles depending on the experimental series. In series 1 (control), the medium was primarily composed of deionized water supplemented with trace element-rich sea salt (Aqua Medic Reef Salt) to ensure that salinity levels were close to $30 \mathrm{ppt}$.

Series 2, on the other hand, utilized water collected from May to September from the Bay of Gdańsk. Before being used to grow $P$. subcrodiformis, it was first filtered through Eurochem medium-grade $\varnothing 12.5$ qualitative filter paper, then sterilized in a Tuttnauer 2840 EL-D autoclave at 
Table 2. Profile of the $P$. subcordiformis biomass used in the experiment.

\begin{tabular}{lcc}
\hline Parameter & Unit & Value \\
\hline Mineral solids (MS) & \% TS & $73.97 \pm 6.23$ \\
Volatile solids (VS) & $\%$ TS & $26.03 \pm 6.23$ \\
Total nitrogen (TN) & $\mathrm{mg} / \mathrm{g}$ VS & $5.32 \pm 1.42$ \\
Total organic carbon (TOC) & $\mathrm{mg} / \mathrm{g}$ VS & $50.74 \pm 15.34$ \\
Total carbon (TC) & $\mathrm{mg} / \mathrm{g}$ VS & $54.34 \pm 11.27$ \\
Protein & $\mathrm{mg} / \mathrm{g}$ VS & $33.25 \pm 4.26$ \\
Lipids & $\% \mathrm{TS}$ & $18.0 \pm 2.0$ \\
$\mathrm{C}: \mathrm{N}$ ratio & - & $10.21 \pm 1.52$ \\
$\mathrm{pH}$ & - & $7.89 \pm 1.02$ \\
\hline
\end{tabular}

$121{ }^{\circ} \mathrm{C}$ for 15 minutes. In all of the experimental series of the first variant, the medium base was supplemented with optimum concentrations of nutrients, as shown in Table 1. In variant 2 , the system was amended with $10 \mathrm{~g} / \mathrm{dm}^{3}$ crystal glucose (AR quality). Detailed profiles of the Bay of Gdańsk water and the growth media are presented in Table 3 .

\subsection{Experimental set-up}

The exact experiment was conducted in a New Brunswick BioFlo 115 bioreactor with an active volume of $2.0 \mathrm{dm}^{3}$ (temperature $25 \pm 1^{\circ} \mathrm{C}$, with intermittent exposure to 5 klux white light under a $14 \mathrm{~h}$ light/10 h dark regime). The FBR was connected to a Mistral 200 air pump with a flow rate of $200 \mathrm{dm}^{3} / \mathrm{h}$. The reactor contents were continuously mixed at $150 \mathrm{rpm}$ using agitator blades. The biomass was separated using a Whatman vacuum membrane filter with a $50 \mathrm{~mm}$ filter insert composed of mixed cellulose esters (porosity $8.0 \mu \mathrm{m}$ ). A pump fitted in the bioreactor sub-unit was used to transfer the medium and the biomass to the filtration system consisting of a filter inserted into a Whatman MBS 1 filtration system, enabling separation of the algal biomass from the growth medium via a Mobil 20 vacuum pump.

\subsection{Analytical methods}

\subsubsection{Qualitative and quantitative analysis of the biomass}

The taxonomic analysis of the algal biomass was done using an MF 346 biological microscope with an Optech 3MP camera. The study included a qualitative analysis of the microalgal biomass used as inoculum in the reactors. Chlorophyll was determined spectrophotometrically after extraction with $90 \%$ acetone. The TS, VS, and MS were measured gravimetrically. Total protein content was estimated by multiplying $\mathrm{TN}$ by a protein conversion factor of 6.25. Lipids were determined using the Soxhlet method with a Buchi extraction apparatus. The $\mathrm{pH}$ determination procedure was as follows: $10 \mathrm{~g}$ of the homogenized airdried sample was weighed out to a $100 \mathrm{~mL}$ beaker; $50 \mathrm{~mL}$ of distilled water was added; the mixture was then stirred; and the $\mathrm{pH}$ of the resultant sample was finally measured with a calibrated apparatus. Total carbon (TC), total organic carbon (TOC), and total nitrogen (TN) were determined using a Shimadzu TOC analyzer.

\subsubsection{Profile of the growth medium}

The water collected from the Bay of Gdańsk for growing $P$. subcordiformis was tested for salinity, dissolved oxygen, and pH using a Hach Lange HQ 440D multi-parameter meter and an Aqua Medic Marine Control Digital salinity meter. Total nitrogen, ammonia nitrogen, total phosphorus, orthophosphates, sulphates, chlorine compounds, iron compounds, and COD were determined using Hach Lange cuvette tests and an UV/VIS DR 5000 spectrophotometer. The same methodology was applied to monitor the levels ofessential nutrients in the culture, i.e., TN and TP. Light intensity was measured with a HANNA HI 97500 luxometer. Glucose concentration in the growth medium was monitored using a YSI 2700 Select analyzer.

\subsection{Statistical analysis}

Each experimental variant was conducted in triplicate. The statistical analysis was conducted and determination coefficient $\mathrm{R}^{2}$ was computed using STATISTICA 13.1 PL (Statistica 13.1 software, StatSoft Inc., Tulsa, OK, USA, 2016). One-way analysis of variance (ANOVA) was used to determine significant differences between the groups. Significant differences between the variables were determined via Tukey's HSD test. Results were considered significant at $p=0.5$.

\section{Results}

The biomass concentration in S1V1 was $3203.3 \pm$ $35.1 \mathrm{mg}_{V S} / \mathrm{dm}^{3}$ (Fig. 1), with chlorophyll levels at 3686.7 $\pm 320.8 \mu \mathrm{g} / \mathrm{dm}^{3}$ (Fig. 2). Biomass growth rate (r) reached $291.21 \pm 3.19 \mathrm{mg}_{V S} / \mathrm{dm}^{3} \cdot \mathrm{d}$. After 11 days of culture, nitrogen and phosphorus were almost completely spent, with levels at $0.61 \pm 0.37 \mathrm{mg} \mathrm{TN} / \mathrm{dm}^{3}$ and $0.04 \pm 0.01 \mathrm{mg}$ $\mathrm{TP} / \mathrm{dm}^{3}$, respectively (Figs. 3,4). The average specific nutrient take-up for biomass growth was $7.00 \pm 0.45 \mathrm{mg}$ $\mathrm{TN} / \mathrm{g}_{V S}$ and $1.69 \pm 0.09 \mathrm{mg} \mathrm{TP} / \mathrm{g}_{V S}$ (Figs. 5,6). In S1V2, amendment of the medium with glucose did not significantly $(p=0.05)$ affect the resulting $P$. subcordiformis population (Table 4). The VS in the PBR was $3348.3 \pm 89.9$ $\mathrm{mg}_{V S} / \mathrm{dm}^{3}$ at $\mathrm{r}=304.39 \pm 8.17 \mathrm{mg}_{V S} / \mathrm{dm}^{3} \cdot \mathrm{d}$ (Fig. 1). On the other hand, significant differences were observed with regard to chlorophyll levels in the system (Table 4). Chlorophyll concentration was $1986.7 \pm 151.7 \mu \mathrm{g} / \mathrm{dm}^{3}$, with mean $\mathrm{r}$ at $180.61 \pm 13.80 \mu \mathrm{g} / \mathrm{dm}^{3} \cdot \mathrm{d}$ (Fig. 2). These values are nearly $50 \%$ lower than those noted in S1V1 (Fig. 2). Nutrients were only partially utilized by the growing $P$. subcordiformis (Figs. 5,6). Phosphorus levels at the end of the culture period were $0.66 \pm 0.09 \mathrm{mg} \mathrm{TP} / \mathrm{dm}^{3}$ (Fig. 4). Nitrogen take-up was approximately $75.70 \pm 0.60 \%$ (Fig. 7), which translates to $\mathrm{N}$ levels of $5.11 \pm 0.13 \mathrm{mg} \mathrm{TN} / \mathrm{dm}^{3}$ (Fig. 3).

The r value in S2V1 was $317.58 \pm 42.31 \mathrm{mg}_{V S} / \mathrm{dm}^{3} \cdot \mathrm{d}$, 
Table 3. Profile of the raw water sourced from the Bay of Gdańsk.

\begin{tabular}{lcccccc}
\hline \multirow{2}{*}{ Parameter } & \multirow{2}{*}{ Unit } & \multirow{2}{*}{ Bay of Gdańsk } & \multicolumn{2}{c}{ Series 1 (S1) } & \multicolumn{2}{c}{ Series 2(S2) } \\
\cline { 4 - 7 } & & & Variant 1 (V1) & Variant 2 (V2) & Variant 1 (V1) & Variant 2(V2) \\
\hline COD & $\mathrm{mg} \mathrm{O}_{2} / \mathrm{dm}^{3}$ & $38.13 \pm 3.96$ & $55.5 \pm 2.01$ & $11033 \pm 57.73$ & $59.97 \pm 0.25$ & $11133 \pm 152$ \\
Ammonia nitrogen & $\mathrm{mg} \mathrm{NH}_{4-} \mathrm{N}_{\mathrm{dm}^{3}}$ & $0.04 \pm 0.01$ & $0.04 \pm 0.01$ & $0.039 \pm 0.01$ & $0.04 \pm 0.01$ & $0.038 \pm 0.01$ \\
Total nitrogen & ${\mathrm{mg} \mathrm{TN} / \mathrm{dm}^{3}}^{*}$ & $0.63 \pm 0.12$ & $21.13 \pm 0.63$ & $20.79 \pm 0.56$ & $21.85 \pm 1.05$ & $21.41 \pm 0.26$ \\
Orthophosphates & $\mathrm{mg} \mathrm{PO}^{3-}{ }_{4} / \mathrm{dm}^{3}$ & $0.18 \pm 0.05$ & $1.85 \pm 0.24$ & $13.53 \pm 0.25$ & $2.95 \pm 0.79$ & $16.6 \pm 0.25$ \\
Total phosphorus & ${\mathrm{mg} \mathrm{TP} / \mathrm{dm}^{3}}$ & $0.06 \pm 0.01$ & $5.00 \pm 0.20$ & $5.04 \pm 0.14$ & $5.05 \pm 0.31$ & $5.27 \pm 0.03$ \\
Sulphates & $\mathrm{mg} \mathrm{SO}^{2-}{ }_{4} / \mathrm{dm}^{3}$ & $413 \pm 5.03$ & $525 \pm 1.00$ & $521 \pm 6.11$ & $538 \pm 2.52$ & $545 \pm 2.57$ \\
Chlorine (I) & $\mathrm{mg} \mathrm{Cl}^{-} / \mathrm{dm}^{3}$ & $2353 \pm 5.77$ & $7510 \pm 10$ & $7318 \pm 2.89$ & $7411 \pm 59.5$ & $7705 \pm 32.88$ \\
Chlorine (II) & $\mathrm{mg} \mathrm{Cl}^{-} / \mathrm{dm}^{3}$ & $333 \pm 2.08$ & $16128 \pm 55.2$ & $16113 \pm 15.26$ & $2380 \pm 156$ & $18240 \pm 20$ \\
Iron (II) & $\mathrm{mg} \mathrm{Fe}^{2+} / \mathrm{dm}^{3}$ & $0.09 \pm 0.01$ & $0.09 \pm 0.01$ & $0.103 \pm 0.06$ & $0.107 \pm 0.01$ & $0.113 \pm 0.02$ \\
Iron (III) & $\mathrm{mg} \mathrm{Fe}^{3+} / \mathrm{dm}^{3}$ & $0.14 \pm 0.02$ & $0.09 \pm 0.01$ & $0.102 \pm 0.07$ & $0.087 \pm 0.01$ & $0.076 \pm 0.01$ \\
pH & - & $7.63 \pm 0.19$ & $8.09 \pm 0.12$ & $8.08 \pm 0.09$ & $8.04 \pm 0.15$ & $8.12 \pm 0.10$ \\
Salinity & - & $30 \pm 0.7$ & $30 \pm 0.9$ & $30 \pm 0.3$ & $31 \pm 0.8$ \\
\hline
\end{tabular}

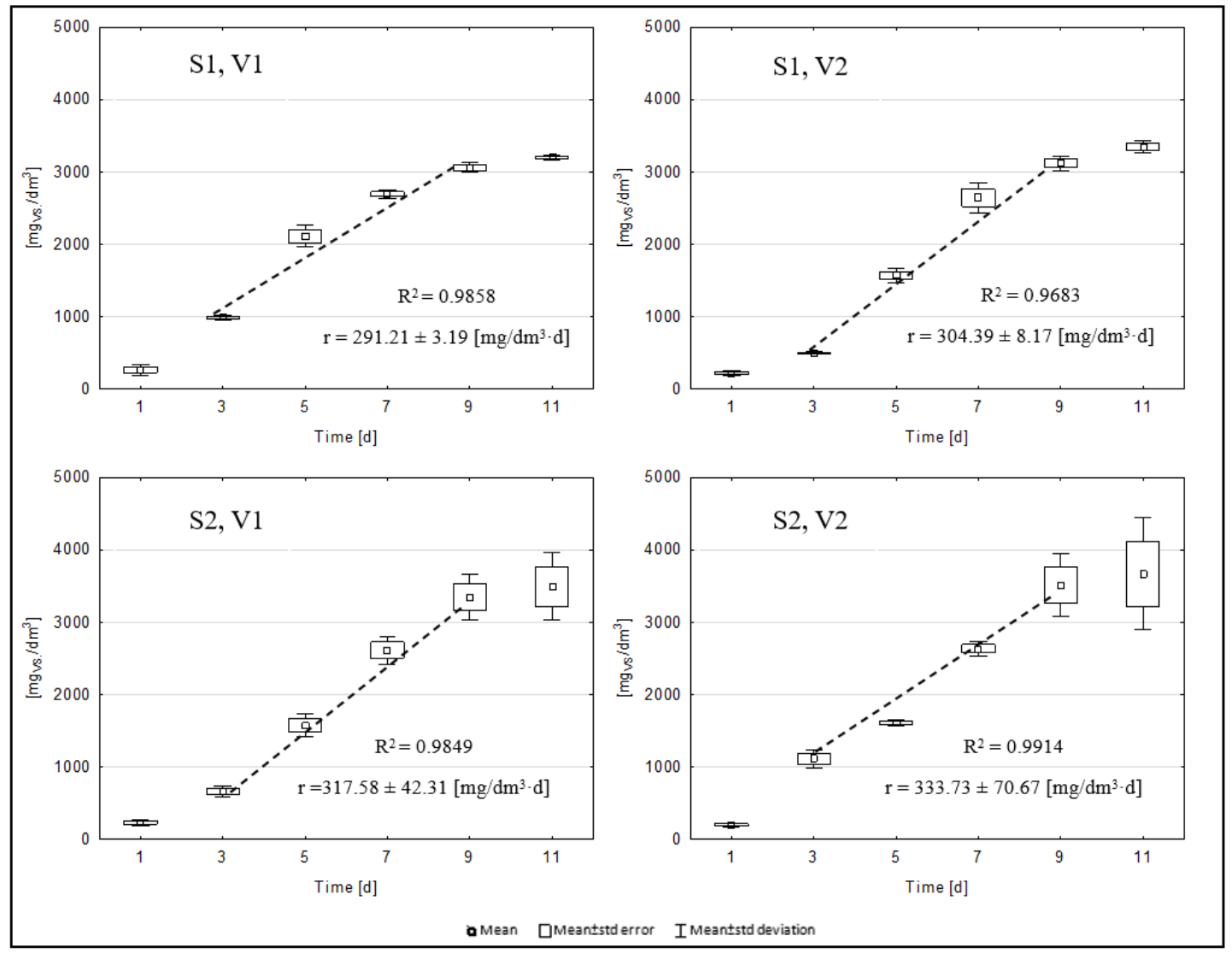

Fig. 1. Trends in VS concentration in the growth medium.

resulting in a biomass concentration of $3493.3 \pm 465.4$ $\mathrm{mg}_{V S} / \mathrm{dm}^{3}$ (Fig. 1). Chlorophyll a levels reached 3845.7 $\pm 696.2 \mu \mathrm{g} / \mathrm{dm}^{3}$ at $\mathrm{r}=349.61 \pm 63.29 \mu \mathrm{g} / \mathrm{dm}^{3} \cdot \mathrm{d}$ (Fig. 2). Nitrogen and phosphorus were found to have been efficiently removed from the growth medium, with their concentrations in the system being $0.39 \pm 0.13 \mathrm{mg} \mathrm{TN} / \mathrm{dm}^{3}$ and $0.02 \pm 0.01 \mathrm{mg} \mathrm{TP} / \mathrm{dm}^{3}$ (Figs. 3,4). Glucose supplementation in S2V2 did not significantly $(p=0.05)$ affect the $P$. subcordiformis growth rate (Table 4$)-$ the biomass concentration was $3671 \pm 777.4 \mathrm{mg}_{V S} / \mathrm{dm}^{3}$ (Fig. 1). The $\mathrm{r}$ level was also similar to the value noted in S2V1 at 333.73 $\pm 70.67 \mathrm{mg}_{V S} / \mathrm{dm}^{3} \cdot \mathrm{d}$. Chlorophyll a level was $1848.3 \pm$ $120.2 \mu \mathrm{g} / \mathrm{dm}^{3}$ (Fig. 2). Nitrogen take-up by the microalgae was close to $67.83 \pm 1.77 \%$ (Fig. 7), which translates to the final $\mathrm{N}$ level of $6.89 \pm 0.37 \mathrm{mg} \mathrm{TN} / \mathrm{dm}^{3}$ (Fig. 3). $\mathrm{N}$ removal was at $4.32 \pm 0.93 \mathrm{mg} \mathrm{TN} / \mathrm{g}_{V S}$ (Fig. 5). The phosphorus concentration at the end of the experiment was 1.05 $\pm 0.06 \mathrm{mg} \mathrm{TP} / \mathrm{dm}^{3}$ (Fig. 4), with the removal rate being 

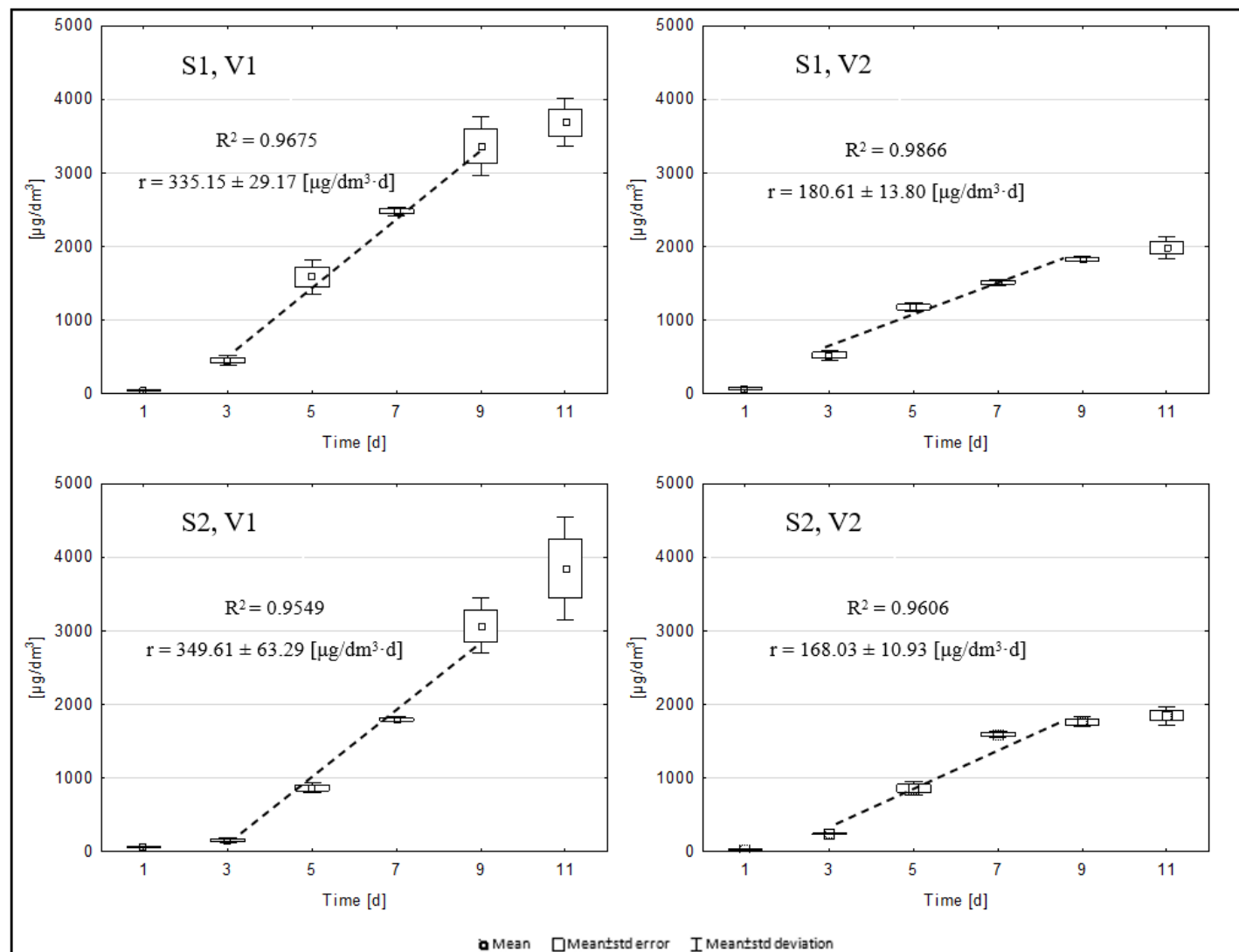

Fig. 2. Trends in chlorophyll a levels.

$79.97 \pm 1.26 \%$ (Fig. 8) and phosphorus take-up per specific biomass growth being $1.25 \pm 0.24 \mathrm{mg} \mathrm{TP} / \mathrm{g}_{V S}$ (Fig. 6). Phosphorus take-up was statistically comparable between the two variants (Table 4). Glucose concentration in the growth medium is presented in Fig. 9.

\section{Discussion}

Use of natural water as growth medium is a novel area of research that very few papers have dealt with so far [31]. Most publications focus on producing P. subcordiformis biomass on media prepared from distilled water and chemical reagents that provide optimal conditions for microalgal growth [24].

Water from Bay of Gdańsk was chosen in order to determine whether natural water is a viable medium for highvolume production of $P$. subcordiformis biomass. The final concentration was $3493.3 \pm 465.4 \mathrm{mg}_{V S} / \mathrm{dm}^{3}$ at a growth rate of $317.58 \pm 42.31 \mathrm{mg}_{V S} / \mathrm{dm}^{3} \cdot \mathrm{d}$. This biomass concentration ise similar to those achieved by other researchers using synthetic and strictly controlled culture conditions on media prepared with distilled water and chemical reagents. Xie et al. [32] have reported $3680 \mathrm{mg}_{V S} / \mathrm{dm}^{3}$ of the final $P$. subcordiformis biomass on the same type of medium, while Ji et al. [30] achieved a biomass production of 3200 $\mathrm{mg}_{V S} / \mathrm{dm}^{3}$ under similar conditions.

The study found that the waters from the coastal zone of the Baltic Sea were too nutrient-deficient to support rapid growth of $P$. subcordiformis biomass. Therefore, the medium had to be supplemented with nitrogen and phosphorus from external sources. Ran et al. [29] reported similar findings after growing $P$. subcordiformis in a medium prepared with water from the southern part of Bohai Bay (China). This led to the conclusion that a satisfactory rate of algal growth can only be achieved with micronutrient supplementation. The final biomass levels in the study ranged from 1.85 to $2.0 \times 10^{6}$ cells $/ \mathrm{cm}^{3}$ [29].

There are also literature reports confirming that Platymonas sp. microalgae can be grown in a blend of municipal sewage and industrial (textile) effluent [33]. The chlorophyll levels were found to be $2.8 \mu \mathrm{g} / \mathrm{cm}^{3}$ for Platymonas suecica and $7.3 \mu \mathrm{g} / \mathrm{cm}^{3}$ for Platymonas chuii. Another study also achieved high rates of nutrient take-up from aquaculture wastewater, with nitrogen and phosphorus removal in the ranges of $87.0-95.0 \%$ and $98.0-99.0 \%$, respectively [34]. These nutrient take-up rates are similar to those achieved in our own research. Almost $100 \%$ of nutrients was utilized in the non-glucose-amended variants. In variants with external carbon source, the nutrient take-up was significantly lower. Possibility of recycling the culture medium composed in sea water for further microalgae cultivation was also investigated. Recirculation is often limited by the increase in salinity due to evaporation and contam- 


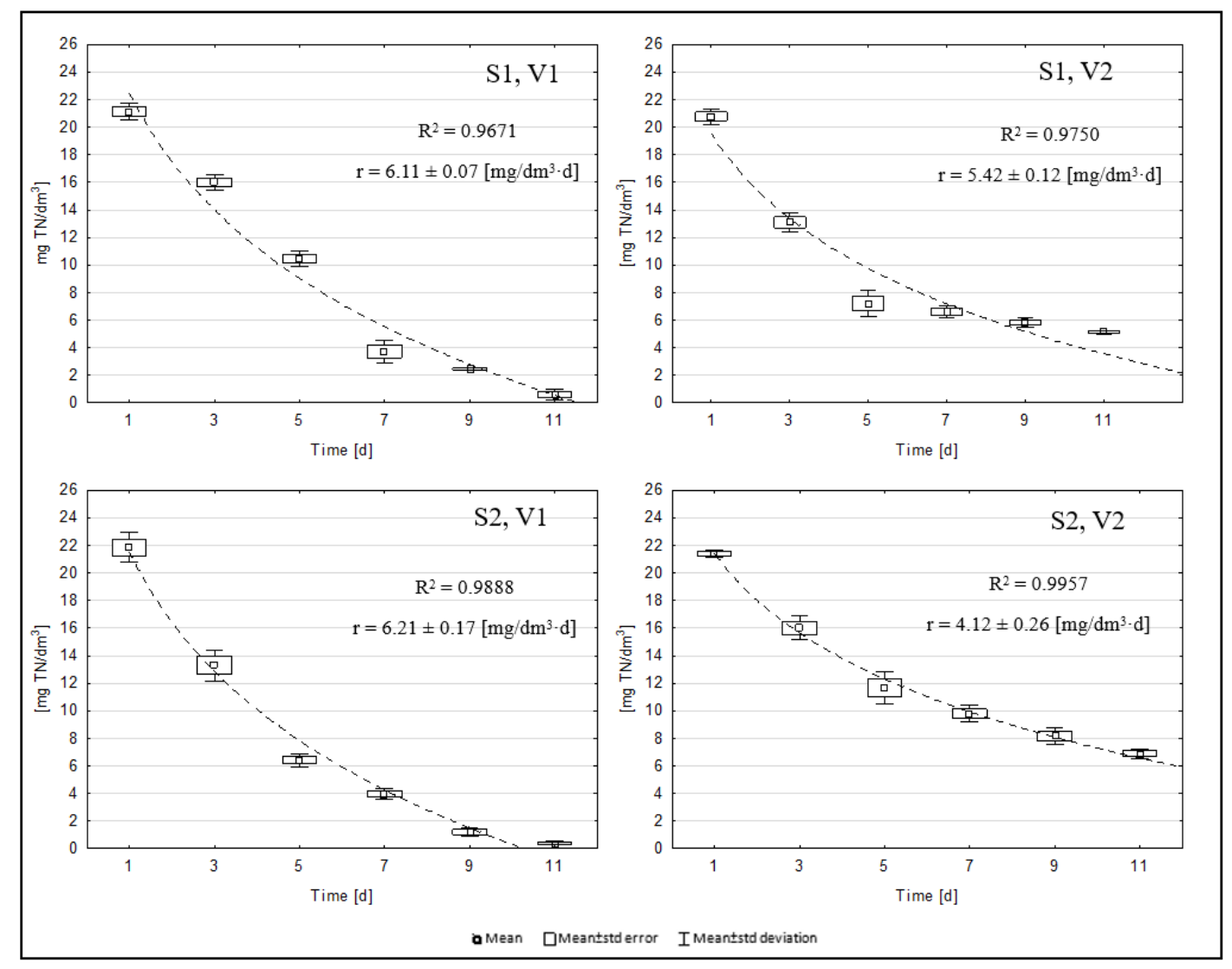

Fig. 3. Trends in TN concentration in the growth medium.

ination. It was proved that despite the increase in salinity from $5.5 \%$ to $12 \%(\mathrm{w} / \mathrm{v})$, microalgae produced $48-160 \%$ more dry organic matter. The peak productivity was $37.5 \pm$ $3.1 \mathrm{~g} \mathrm{VS} \mathrm{m}^{2} /$ day. The combination of mixotrophic growth ensuring high biomass yield under conditions of high salinity has been proven to be an effective sustainable cultivation strategy [35].

Most studies use closed culture systems due to the need to monitor and culture multiple process parameters that directly affect microalgal growth in hydrogen production systems [36]. Most literature reports focus on PBRs with active volumes of $250-5000 \mathrm{~cm}^{3}$ [37]. A P. subcordiformis biomass grown by Guo et al. [38] in a column reactor reached levels that correspond to a phytoplankton concentration of $4.0 \times 10^{6}$ cells $/ \mathrm{cm}^{3}$, which translates to algal mass levels of $2500 \mathrm{mg}_{T S} / \mathrm{dm}^{3}$. Ji et al. [39] obtained a $P$. subcordiformis biomass concentration of $1800 \mathrm{mg}_{T S} / \mathrm{dm}^{3}$ in a study conducted in an airlift tubular reactor with a working volume of $500 \mathrm{~cm}^{3}$. Given the strictly controlled nature of microalgal biomass production, this set-up enabled multiparametric monitoring of the culture $[36,40]$. One example of this design is the PBR used by Ji et al. [30] to cultivate $P$. subcordiformis. The authors obtained a microalgal biomass concentration of $3200 \mathrm{mg}_{T S} / \mathrm{dm}^{3}$.
In the present study, we also utilized a bioreactor capable of monitoring the process parameters important for micoalgal cultivation, and grew a culture of $P$. subcordiformis. The final biomass concentration exceeded 3200 $\mathrm{mg}_{V S} / \mathrm{dm}^{3}$ - beinge significantly higher than the values reported by the above-cited authors. Xie et al. [32] used a similar type of PBR to produce similar levels of P. subcordiformis biomass at $3680 \mathrm{mg}_{T S} / \mathrm{dm}^{3}$. The culture was grown under mixotrophic conditions with glucose as an exogenous source of carbon. Initial glucose levels in the medium were $24 \mathrm{~g} / \mathrm{dm}^{3}$ [32]. In the present experiment, initial glucose level chosen was lower and reached $10 \mathrm{~g} / \mathrm{dm}^{3}$. This decision was supported by the results of preliminary studies, in which attempts to test higher doses of glucose led to high turbidity of the culture medium. This blocked the light and thus directly arrested the growth of P. subcordiformis. Our own research showed that the final P. subcordiformis biomass levels fell within the relatively narrow range of 3200 to $3790 \mathrm{mg}_{V S} / \mathrm{dm}^{3}$ across all experimental variants. However, the trends in biomass concentration in the PBR were different when chlorophyll a levels were used to measure this parameter. Variants with glucose dosing had nearly $50 \%$ lower concentrations of $P$. subcordiformis biomass measured by chlorophyll a levels compared to variants with no external carbon source. 

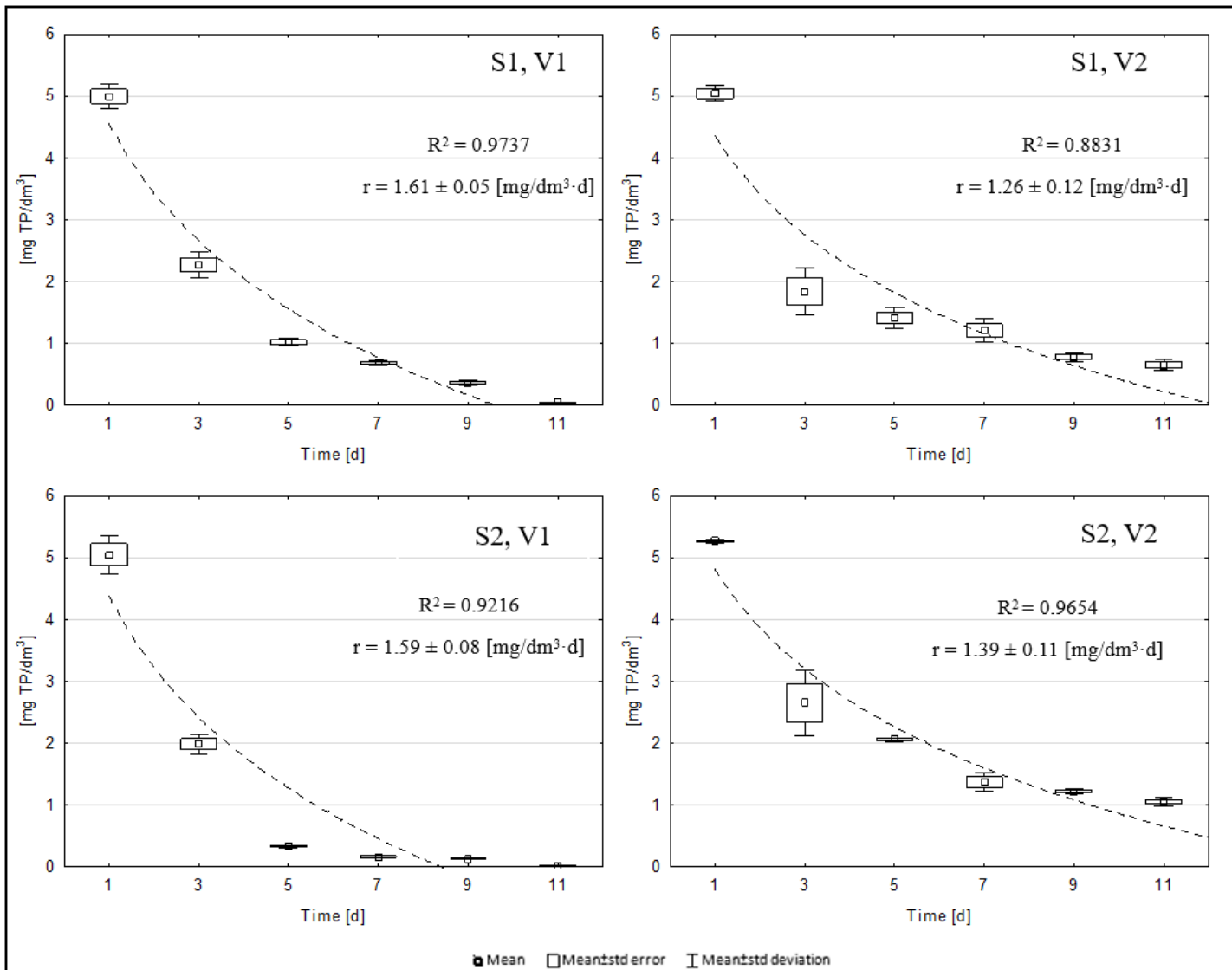

Fig. 4. Trends in TP concentration in the growth medium.

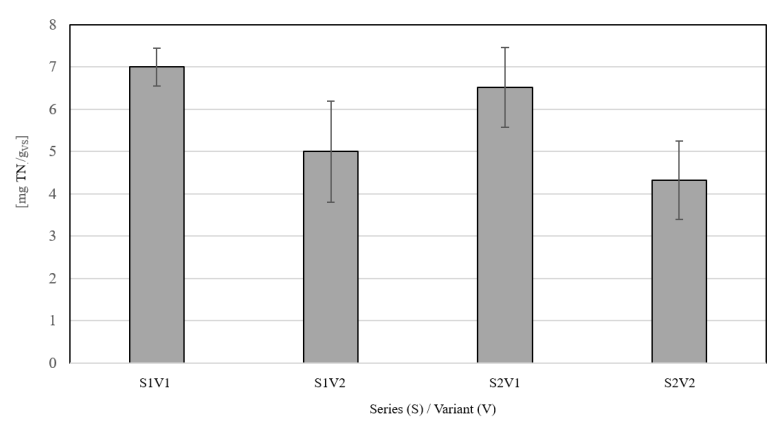

Fig. 5. TN take-up per specific gain of $P$. subcordiformis VS.

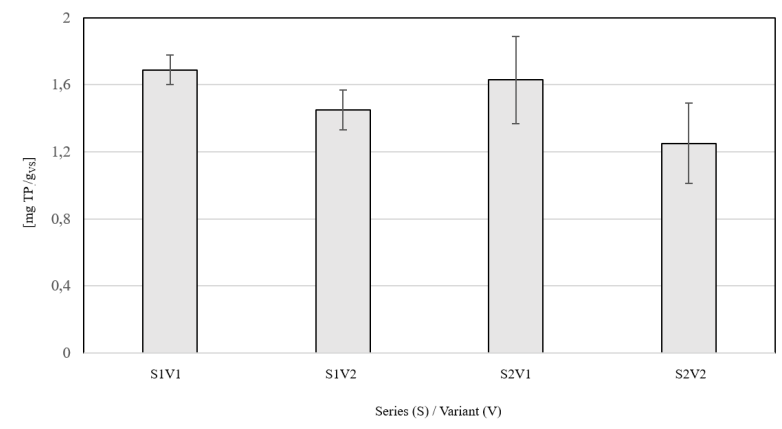

Fig. 6. TP take-up per specific gain of $P$. subcordiformis VS.

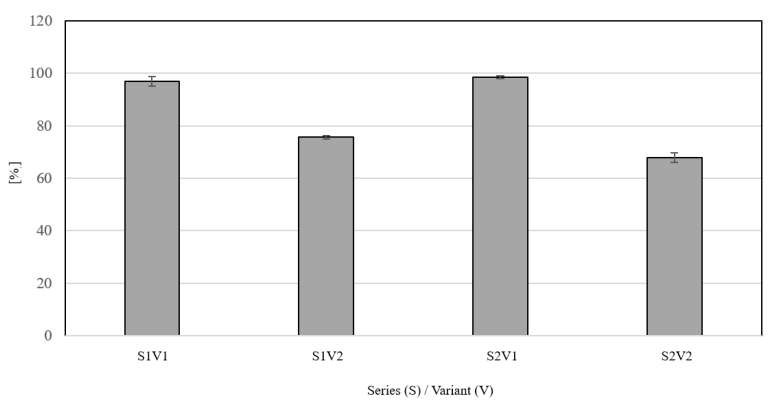

Fig. 7. Efficiency of TN removal by $P$. subcordiformis.

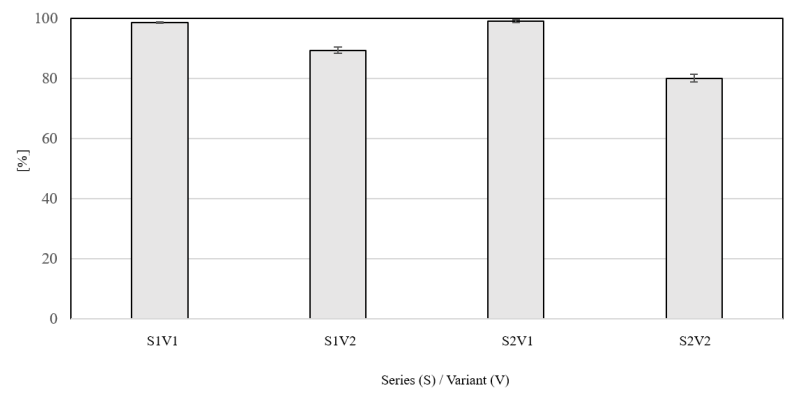

Fig. 8. Efficiency of TP removal by $P$. subcordiformis. 
Table 4. Results of the Tukey HSD comparative analysis.

\begin{tabular}{|c|c|c|c|c|c|c|c|c|}
\hline \multirow{3}{*}{ Experimental series/variant } & \multicolumn{8}{|c|}{ Nutrient take-up per specific gain of $P$. subcordiformis VS } \\
\hline & \multicolumn{4}{|c|}{$\mathrm{TN}$} & \multicolumn{4}{|c|}{$\mathrm{TP}$} \\
\hline & S1V1 & S1V2 & $\mathrm{S} 2 \mathrm{~V} 1$ & $\mathrm{~S} 2 \mathrm{~V} 2$ & S1V1 & S1V2 & S2V1 & $\mathrm{S} 2 \mathrm{~V} 2$ \\
\hline S1-V1 & & 0.070680 & 0.993059 & 0.011031 & & 0.653611 & 0.984588 & 0.236786 \\
\hline $\mathrm{S} 1-\mathrm{V} 2$ & 0.070680 & & 0.168430 & 0.869060 & 0.653611 & & 0.943876 & 0.951561 \\
\hline $\mathrm{S} 2-\mathrm{V} 1$ & 0.993059 & 0.168430 & & 0.027432 & 0.984588 & 0.943876 & & 0.538081 \\
\hline S2-V2 & 0.011031 & 0.869060 & 0.027432 & & 0.236786 & 0.951561 & 0.538081 & \\
\hline \multirow{3}{*}{ Experimental series/variant } & \multicolumn{8}{|c|}{ Efficiency of nutrient removal by $P$. subcordiformis } \\
\hline & \multicolumn{4}{|c|}{$\mathrm{TN}$} & \multicolumn{4}{|c|}{$\mathrm{TP}$} \\
\hline & S1V1 & $\mathrm{S} 1 \mathrm{~V} 2$ & S1V1 & $\mathrm{S} 1 \mathrm{~V} 2$ & S1V1 & S1V2 & S1V1 & $\mathrm{S} 1 \mathrm{~V} 2$ \\
\hline S1-V1 & & 0.000159 & 0.991833 & 0.000159 & & 0.000159 & 0.991833 & 0.000159 \\
\hline $\mathrm{S} 1-\mathrm{V} 2$ & 0.000159 & & 0.000159 & 0.027120 & 0.000159 & & 0.000159 & 0.027120 \\
\hline S2-V1 & 0.991833 & 0.000159 & & 0.000159 & 0.991833 & 0.000159 & & 0.000159 \\
\hline S2-V2 & 0.000159 & 0.027120 & 0.000159 & & 0.000159 & 0.027120 & 0.000159 & \\
\hline \multirow{3}{*}{ Experimental series/variant } & \multicolumn{8}{|c|}{ VS and chlorophyll in growth medium at the end of the growth period } \\
\hline & \multicolumn{4}{|c|}{ VS } & \multicolumn{4}{|c|}{ chlorophyll a } \\
\hline & S1V1 & S1V2 & S1V1 & S1V2 & S1V1 & S1V2 & S1V1 & S1V2 \\
\hline S1-V1 & & 0.998996 & 0.975066 & 0.843580 & & 0.000494 & 0.989136 & 0.000307 \\
\hline $\mathrm{S} 1-\mathrm{V} 2$ & 0.998996 & & 0.998996 & 0.961028 & 0.000494 & & 0.000290 & 0.994234 \\
\hline S2-V1 & 0.975066 & 0.998996 & & 0.997306 & 0.989136 & 0.000290 & & 0.000220 \\
\hline S2-V2 & 0.843580 & 0.961028 & 0.997306 & & 0.000307 & 0.994234 & 0.000220 & \\
\hline
\end{tabular}

$*$ - values in italics are significant at $p \leq 0.05$.

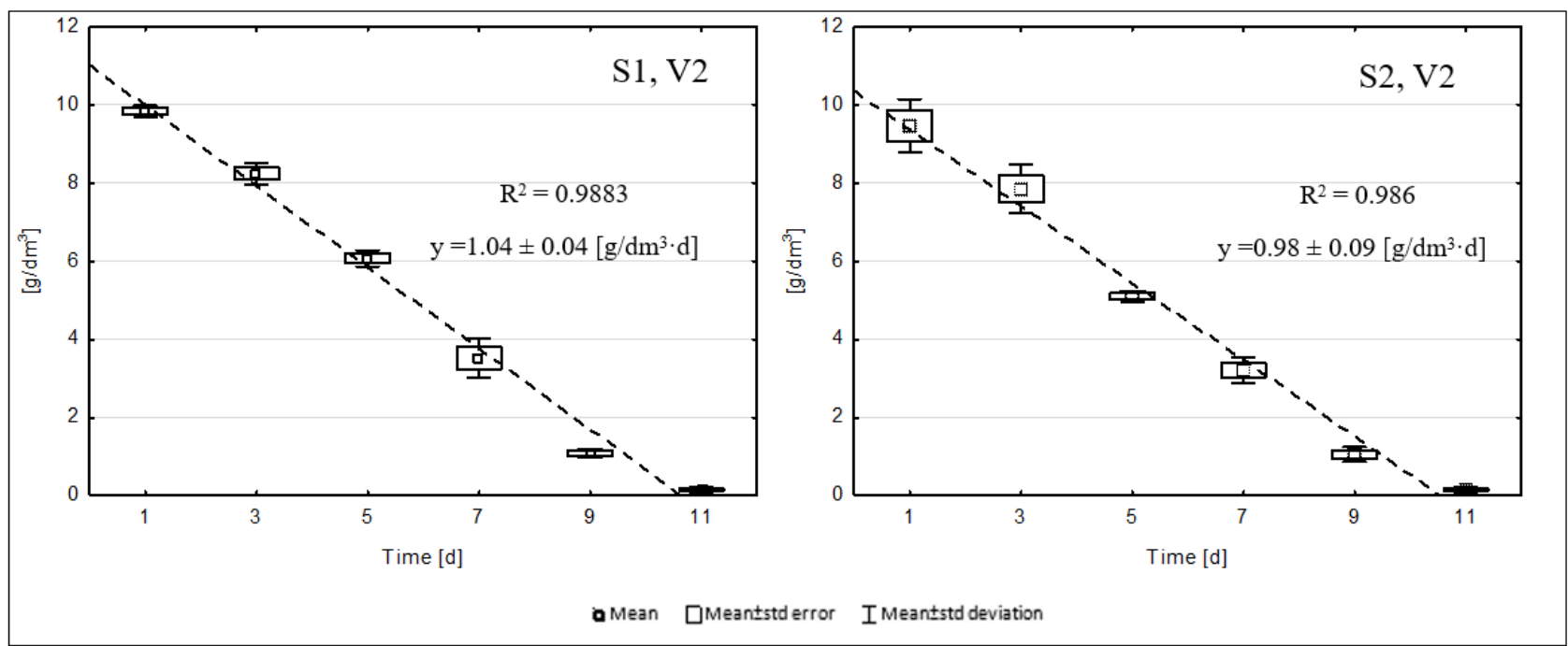

Fig. 9. Changes in glucose levels in the growth medium.

Xie et al. [32] also found decreased chlorophyll content in P. subcordiformis cultures stimulated by added glucose. The chlorophyll content in the photoautotrophic culture (without external carbon source) was, on average, twice as high than in the mixotrophic culture with added glucose [32]. A similar trend was observed by Faraloni et al. [41] in a Chlamydomonas reinhardtii culture grown in a medium made from wastewater rich in organic acids and carbohydrates. Chlorophyll content was $25 \mathrm{mg} / \mathrm{dm}^{3}$, be- ing significantly lower than in the control microalgae culture grown in a mineral medium $\left(50 \mathrm{mg} / \mathrm{dm}^{3}\right.$ chlorophyll a). The culture was grown mixotrophically at $28^{\circ} \mathrm{C}$ and exposed to $70 \mu \mathrm{mol} \mathrm{E} / \mathrm{m}^{2} \cdot \mathrm{s}$ light. In the control, the chlorophyll concentration grew throughout the experiment $(70 \mathrm{~h})$ and stabilized only at the last stage of growth. In contrast, the stabilization occurred just after $20 \mathrm{~h}$ in the culture supplemented with industrial wastewater, with the biomass remaining stable afterwards [41]. 
Fluctuations in the level of photosynthetic pigments can occur in response to changes in microbial metabolism in photoautotrophic and mixotrophic conditions. In the autotrophic culture, microalgal growth is fuelled directly by photosynthesis (which in turn is driven by light energy). In mixotrophic environments, an additional source of energy is provided in the form of an external carbon substrate (easily degradable organic compounds). However, this additional energy source inhibits photosynthesis, which stimulates the formation of pigments in microalgae such as $P$. subcordiformis [42].

\section{Conclusions}

Growing P. subcordiformis in water sourced from the Bay of Gdańsk led to high biomass growth rates, comparable with those observed when using growth media based on deionized water and chemical reagents. It was found that water sourced from the coastal zone of the Baltic Sea was too nutrient-deficient to support rapid growth of $P$. subcordiformis biomass, therefore, the medium had to be supplemented with nitrogen and phosphorus from external sources. Amendment of the growth medium with glucose significantly limited chlorophyll production in microalgal cells, thus resulting in lower chlorophyll levels than in the variants with no external carbon source. The glucose-amended variants had significantly higher nitrogen and phosphorus levels in the medium at the end of the growth period. The use of mixotrophic culture allowed to obtain significantly higher efficiency of $P$. subcordiformis culture grow characterized by the final concentration of dry organic matter. The use of natural sea waters has been proven to be justified from a technological and economic point of view.

\section{Author contributions}

MDu and MDę designed the research study. MDu and AN performed the research. MZ provided help and advice. $\mathrm{MDu}, \mathrm{MDe}$ and MZ analyzed the data. MDę and JK wrote the manuscript. All authors contributed to editorial changes in the manuscript. All authors read and approved the final manuscript.

\section{Ethics approval and consent to participate}

Not applicable.

\section{Acknowledgment}

Not applicable.

\section{Funding}

The manuscript was supported by Project financially supported by Minister of Education and Science in the range of the program entitled "Regional Initiative of Excellence" for the years 2019-2022, project no. 010/RID/2018/19, amount of funding: 12,000,000 PLN, and the work WZ/WB-IIŚ/2/2019, funded by the Minister of Education and Science.

\section{Conflict of interest}

The authors declare no conflict of interest.

\section{References}

[1] Anca-Couce A, Hochenauer C, Scharler R. Bioenergy technologies, uses, market and future trends with Austria as a case study. Renewable and Sustainable Energy Reviews. 2021; 135: 110237.

[2] Bhatia L, Bachheti RK, Garlapati VK, Chandel AK. Thirdgeneration biorefineries: a sustainable platform for food, clean energy, and nutraceuticals production. Biomass Conversion and Biorefinery. 2020: 1-16.

[3] Kazimierowicz J, Dzienis L. Giant miscanthus as a substrate for biogas production. Journal of Ecological Engineering. 2015; 16: 139-142.

[4] Di Maria F, Sisani F. Replacing energy crops with bio-waste for an existing anaerobic digestion plant: Energetic and carbon footprint in a LCA perspective. Energy Procedia. 2017; 126: $377-$ 384.

[5] Dębowski M, Zieliński M, Świc, I, Kazimierowicz J. Algae Biomass as a Potential Source of Liquid Fuels. Phycology. 2021; 1: $105-118$.

[6] Yawson DO, Mulholland BJ, Ball T, Adu MO, Mohan S, White PJ. Effect of Climate and Agricultural Land Use Changes on UK Feed Barley Production and Food Security to the 2050s. Land. 2017; 6: 74 .

[7] Popp J, Kot S, Lakner Z, Oláh J. Biofuel use: Peculiarities and implications. Journal of Security \& Sustainability Issues. 2018; 7: 477-493.

[8] Puricelli S, Cardellini G, Casadei S, Faedo D, van den Oever AEM, Grosso M. A review on biofuels for light-duty vehicles in Europe. Renewable and Sustainable Energy Reviews. 2021; 137: 110398.

[9] Kim EJ, Kim S, Choi H, Han SJ. Co-production of biodiesel and bioethanol using psychrophilic microalga Chlamydomonas sp. KNM0029C isolated from Arctic sea ice. Biotechnology for Biofuels. 2020; 13: 20.

[10] Kupczyk A, Mączyńska-Sęczek J, Golisz E, Borowski PF. Renewable Energy Sources in Transport on the Example of Methyl Esters and Bioethanol. Processes. 2020; 8: 1610.

[11] Kothari R, Pandey A, Ahmad S, Kumar A, Pathak VV, Tyagi VV. Microalgal cultivation for value-added products: a critical enviro-economical assessment. 3 Biotech. 2020; 7: 243.

[12] Zhang C, Chen X, Too H. Microbial astaxanthin biosynthesis: recent achievements, challenges, and commercialization outlook. Applied Microbiology and Biotechnology. 2020; 104: 5725-5737.

[13] Martínez JM, Gojkovic Z, Ferro L, Maza M, Álvarez I, Raso J, et al. Use of pulsed electric field permeabilization to extract astaxanthin from the Nordic microalga Haematococcus pluvialis. Bioresource Technology. 2019; 289: 121694.

[14] Leone GP, Balducchi R, Mehariya S, Martino M, Larocca V, Di Sanzo G, et al. Selective Extraction of $\omega-3$ Fatty Acids from Nannochloropsis sp. Using Supercritical CO2 Extraction. Molecules. 2019; 24: 2406.

[15] Kujawska N, Talbierz S, Dębowski M, Kazimierowicz J, Zieliński M. Effect of the Concentration of Extracellular Polymeric Substances (EPS) and Aeration Intensity on Waste Glycerol Valorization by Docosahexaenoic Acid (DHA) Produced in Heterotrophic Culture of Schizochytrium sp. Applied Sciences. 2021; 11: 9573. 
[16] Kujawska N, Talbierz S, Dębowski M, Kazimierowicz J, Zieliński M. Cultivation Method Effect on Schizochytrium sp. Biomass Growth and Docosahexaenoic Acid (DHA) Production with the Use of Waste Glycerol as a Source of Organic Carbon. Energies. 2021; 14: 2952.

[17] Kujawska N, Talbierz S, Dębowski M, Kazimierowicz J, Zieliński M. Optimizing Docosahexaenoic Acid (DHA) Production by Schizochytrium sp. Grown on Waste Glycerol. Energies. 2021; 14: 1685.

[18] Debnath C, Bandyopadhyay TK, Bhunia B, Mishra U, Narayanasamy S, Muthuraj M. Microalgae: Sustainable resource of carbohydrates in third-generation biofuel production. Renewable and Sustainable Energy Reviews. 2021; 150: 111464.

[19] Borowiak D, Lenartowicz P, Grzebyk M, Wiśniewski M, Lipok J, Kafarski P. Novel, automated, semi-industrial modular photobioreactor system for cultivation of demanding microalgae that produce fine chemicals - the next story of $\mathrm{H}$. pluvialis and astaxanthin. Algal Research. 2021; 53: 102151.

[20] Siddiki SYA, Mofijur M, Kumar PS, Ahmed SF, Inayat A, Kusumo F, et al. Microalgae biomass as a sustainable source for biofuel, biochemical and biobased value-added products: an integrated biorefinery concept. Fuel. 2022; 307: 121782.

[21] Chew KW, Chia SR, Show PL, Yap YJ, Ling TC, Chang J. Effects of water culture medium, cultivation systems and growth modes for microalgae cultivation: a review. Journal of the Taiwan Institute of Chemical Engineers. 2018; 91: 332-344.

[22] Calhoun S, Bell TAS, Dahlin LR, Kunde Y, LaButti K, Louie $\mathrm{KB}$, et al. A multi-omic characterization of temperature stress in a halotolerant Scenedesmus strain for algal biotechnology. Communications Biology. 2021; 4: 333.

[23] Dębowski M, Zieliński M, Kazimierowicz J, Kujawska N, Talbierz S. Microalgae Cultivation Technologies as an Opportunity for Bioenergetic System Development-Advantages and Limitations. Sustainability. 2020, 12: 9980.

[24] Metsoviti M N, Papapolymerou G, Karapanagiotidis I T, Katsoulas N. Effect of Light Intensity and Quality on Growth Rate and Composition of Chlorella vulgaris. Plants. 2020, 9: 31.

[25] Qi M, Yao C, Sun B, Cao X, Fei Q, Liang B, et al. Application of an in situ $\mathrm{CO} 2$-bicarbonate system under nitrogen depletion to improve photosynthetic biomass and starch production and regulate amylose accumulation in a marine green microalga Tetraselmis subcordiformis. Biotechnology for Biofuels. 2020; 12: 184.

[26] Yao C, Jiang J, Cao X, Liu Y, Xue S, Zhang Y. Phosphorus Enhances Photosynthetic Storage Starch Production in a Green Microalga (Chlorophyta) Tetraselmis subcordiformis in Nitrogen Starvation Conditions. Journal of Agricultural and Food Chemistry. 2018; 66: 10777-10787.

[27] Dudek M, Dębowski M, Zieliński M, Nowicka A, Rusanowska P. Water from the Vistula Lagoon as a medium in mixotrophic growth and hydrogen production by Platymonas subcordiformis. International Journal of Hydrogen Energy. 2018; 43: 9529 9534.

[28] Guo Z, Li Y, Guo H. Effect of Light/Dark Regimens on Hydrogen Production by Tetraselmis subcordiformis Coupled with an Alkaline Fuel Cell System. Applied Biochemistry and Biotechnology. 2017; 183: 1295-1303.
[29] Ran C, Zhang F, Sun H, Zhao B. Effect of culture medium on hydrogen production by sulfur-deprived marine green algae Platymonas subcordiformis. Biotechnology and Bioprocess Engineering. 2009; 14: 835-841.

[30] Ji C, Legrand J, Pruvost J, Chen Z, Zhang W. Characterization of hydrogen production by Platymonas Subcordiformis in torus photobioreactor. International Journal of Hydrogen Energy. 2010; 35: 7200-7205.

[31] Pang H, Wang Y, Chi Z, Xu Y, Li S, Che J, et al. Enhanced aquaculture effluent polishing by once and repetitive nutrients deprived seawater Chlorella sp. Algal Research. 2021; 60: 102555.

[32] Xie J, Zhang Y, Li Y, Wang Y. Mixotrophic cultivation of Platymonas subcordiformis. Environmental Biology of Fishes. 2001; 13: $343-347$.

[33] Chinnasamy S, Bhatnagar A, Hunt RW, Das KC. Microalgae cultivation in a wastewater dominated by carpet mill effluents for biofuel applications. Bioresource Technology. 2010; 101: 3097-3105.

[34] Guo Z, Liu Y, Guo H, Yan S, Mu J. Microalgae cultivation using an aquaculture wastewater as growth medium for biomass and biofuel production. Journal of Environmental Sciences (China). 2016; 25: S85-S88.

[35] Fon Sing S, Isdepsky A, Borowitzka MA, Lewis DM. Pilot-scale continuous recycling of growth medium for the mass culture of a halotolerant Tetraselmis sp. in raceway ponds under increasing salinity: a novel protocol for commercial microalgal biomass production. Bioresource Technology. 2015; 161: 47-54.

[36] Dasgupta CN, Jose Gilbert J, Lindblad P, Heidorn T, Borgvang SA, Skjanes K, et al. Recent trends on the development of photobiological processes and photobioreactors for the improvement of hydrogen production. International Journal of Hydrogen Energy. 2010; 35: 10218-10238.

[37] Porto B, Gonçalves AL, Esteves AF, de Souza SMAGU, de Souza AAU, Vilar VJP, et al. Assessing the potential of microalgae for nutrients removal from a landfill leachate using an innovative tubular photobioreactor. Chemical Engineering Journal. 2021; 413: 127546.

[38] Guo Z, Chen Z, Lu H, Fu Y, Yu X, Zhang W. Sustained hydrogen photoproduction by marine green algae platymonas subcordiformis integrated with in situ hydrogen consumption by an alkaline fuel cell system. Journal of Biotechnology. 2008; 136: S573.

[39] Ji C, Yu X, Chen Z, Xue S, Legrand J, Zhang W. Effects of nutrient deprivation on biochemical compositions and photohydrogen production of Tetraselmis subcordiformis. International Journal of Hydrogen Energy. 2011; 36: 5817-5821.

[40] Oncel S, Sukan FV. Effect of light intensity and the light: dark cycles on the long term hydrogen production of Chlamydomonas reinhardtii by batch cultures. Biomass and Bioenergy. 2011; 35: 1066-1074.

[41] Faraloni C, Ena A, Pintucci C, Torzillo G. Enhanced hydrogen production by means of sulfur-deprived Chlamydomonas reinhardtii cultures grown in pretreated olive mill wastewater. International Journal of Hydrogen Energy. 2011; 36: 5920-5931.

[42] RanW, Xiang Q, Pan Y, Xie T, Zhang Y, Yao C. Enhancing photosynthetic starch production by $\gamma$-aminobutyric acid addition in a marine green microalga tetraselmis subcordiformis under nitrogen stress. Industrial \& Engineering Chemistry Research. 2020; 59: 17103-17112. 